\title{
Teacher Perception toward Thematic Learning of Indonesian Curricullum at First Class of Elementary School
}

\author{
V Anggraini ${ }^{1}$, S Edriati $^{2}$, A D Maharani ${ }^{3}$, L Husnita $^{4}$ \\ STKIP PGRI Sumatera Barat \\ \{villia@stkip-pgri-sumbar.ac.id ${ }^{1}$, sofia@stkip-pgri-sumbar.ac.id², adedewimaharani@stkip-pgri- \\ sumbar.ac.id ${ }^{3}$, liza@stkip-pgri-sumbar.ac.id $\left.{ }^{4}\right\}$
}

\begin{abstract}
This study aimed to determine a teacher's perception of first class of elementary school toward thematic learning. Data collection used in-depth interview techniques for elementary school teachers in Luhak Tanah Datar and Luhak Agam. Data was conducted qualitatively. The results of the interview indicates that the teachers do not understand thematic learning comprehensively. Teachers assume that new thematic learning models can be applied if students have already been good at reading, writing, and counting. This condition affects on the thematic learning process conducted by teachers requiring prospective first-class elementary school students to be able to read and write.
\end{abstract}

Keywords: Thematic, Curriculum, Teacher Perception, Elementary School

\section{INTRODUCTION}

Ages of Elementary School ranges generally from 7 to 12 years old. In Indonesian like in japan, elementary school lasts for six years, almost all children also attend one or more years of preschool before they enter elementary school [1]. Elementary Schools usually serve children from seven to twelve years old. Basic education is very important for students because at that age students are taught discipline, skills, and behavior and aware the environment. Those students are expected to interact and socialize with teachers, friends, and their community [2]. At the elementary school level, affective domain must be more introduced, taught, or exemplified to children compared to the other domain such cognitive and psychomotor.

Focus of education of Elementary School students is on the building the student attitude and character. Character education is an attempt to optimize students' ethical behavior [3]. The right time to develop and character education that is good from an early age is through elementary school [4]. Strengthening character habituation needs to be done so that students fully understand what is right and wrong, schools should also choose a character education model tailored to the student's age and condition of the student [5]. Therefore, the Indonesian curriculum tries to inform a thematic approach in elementary school learning.

Thematic learning or theme-based learning is to learn an integrated knowledge by defining a central "theme", at the very start and compose related knowledge surrounds the central theme from various aspects [6]. This thematic approach views learning activities holistically and reflects the real world interactively. The implementation of this thematic learning approach departs from a topic or theme chosen and developed by the teacher together with the 
pupils [7]. According to [8] "Thematic learning emphasizes the theme as the union of various subjects preferred with the meaning of learning and the relevance of various concepts. Thematic learning provides direct experience to students ". [9] State that thematic learning is developed based on research activities, where students are faced with facts, physical, social and interaction phenomena, to build relationships between their context and their knowledge.

The rising problem in the application of thematic learning is teacher readiness. The teacher does not understand the philosophy of thematic learning. As a result, the application of thematic learning in the classroom becomes problematic. [10] states that teachers are not ready to apply thematic learning methods. Universities in Indonesia have not designed generally thematic learning, so students are not ready to apply thematic learning methods. The purpose of this study was to find out more about the teacher perception implementing Indonesian curriculum at first class of elementary school

\section{RESEARCH METHOD}

This research was a descriptive study aiming to determine the teacher's perception of elementary school implementing thematic learning. Data were collected by Teacher in-depth interviews at first class of elementary school. The subject of this study was the first class teacher at SDN 01 Mandahiling Pagaruyung-Batusangkar, SDN 15 Pagaruyung, SDN 20 Lubuk Alung, Ampek Nagari, and SDN 11 Pudung, Agam Regency. Technique of analyzing data from interviews used triangulation techniques, namely reducing data, presenting data and drawing conclusions [11]. Reducing data was an activity of selecting, focusing, abstracting and transforming raw data.

\section{RESULT AND DISCUSSION}

Based on the results of in-depth interviews with first class of Elementary School teachers at SDN 01 Mandahiling Pagaruyung, it shows that the implementation of thematic learning is very creative in guiding first class students, especially in building character values. However, the application of thematic learning has not been done in an integrated manner. Teachers still tend to separate teaching material based on subjects in the thematic learning process. The teachers also does not understand the achievements of learning for first class elementary school students. This condition is seen where the teacher separates the process of reading, writing, and counting from thematic learning. The teacher still demands them to be able to read, write, and count before doing thematic learning. Students who have not been able to read, write, and count are given additional lessons by the teacher and parents are also asked to teach students to read, write, and count at home.

Teachers of SDN 20 Lubuk Alung say that they are still in the learning stage to teach themes and even the learning time is not sufficient to teach each sub-theme. In this school, the teachers also assumes that being able to apply thematic learning, students must be able to read, write, and count. Therefore, prospective first-year students are also required to have to be able to read, write, and count. Some students who are not able to read, write, and count are given an additional study schedule after finishing school for the material to read, write, and count by the teacher.

Those conditions that are not much different at SDN 11 Pudung. The teachers still teach the ability to read, write, and count outside of the theme. Schools provide special study hours outside of school hours to teach students to read, write, and count. Yet, different conditions are found in SDN 15 Pagaruyung. The first class teacher said that thematic learning is mutually 
integrated or connected to each field of study. The ability to read and write of students is taught through thematic learning. The teachers carry out the thematic learning process through telling stories and playing. There are more activities carried out in thematic learning. Students learn to read, write, and count through storytelling and playing activities applied by the teacher. Interviews conducted with first class teachers at SDN 15 Pagaruyung shows that the teacher deeply understand the nature of the thematic learning applied at the school. Thematic learning can involve skills such as reading, thinking, remembering and writing real-life contexts could encourage creative explorations. By implementing a learning model that is integrated with the learning process with careful planning, integrated implementation, and objective learning outcomes, by considering aspects of competence, knowledge and skills, will collect learning processes and outcomes that are in accordance with educational goals [12].

Those observed Elementary Schools show different teacher perceptions and insufficient of teacher knowledge into thematic learning. As stated [10] that teachers in Indonesia are not ready to implement thematic learning. In [13] it is stated that the teacher's understanding of Indonesian curriculum is still weak. Based on the results of interviews with teachers in the four elementary schools, it can be concluded that the implementation of learning in the first grade of Elementary School has sought the use of thematic learning models but the perception and understanding of teachers have not related to the Indonesian curriculum requirements.

The principal of SDN 11 Pudung say that first class teachers are not able to understand the learning outcomes where it is actually expected for first class students of elementary school. The teachers teach the first class students to be able to read, write and count. Therefore, there should be training for teachers on thematic learning strategies, so that the learning outcomes are achieved. The same thing is also expressed by the principal of SDN 20 Lubuk Alung stating that there is a need for formal training for teachers so that teachers could review the requirement of Indonesian curriculum. It would be better if there is a learning model that can be a reference for teachers to teach reading, writing and counting with thematic concepts. In [14] stated that the implementation of the Indonesian curriculum has not been balanced with the readiness of teachers who are required to be more creative and innovative, in fact still far from expectations, for example the interest of educators to make teaching materials independently is still very lacking. Character education is an inclusive concept regarding all aspects of how families, schools, and related social institutions support the positive character development of children and adults [15]. Therefore, when character education is questioned, the role of the teacher becomes more important [16] [17].

\section{CONCLUSIONS}

Based on the results of the interview, it is concluded that the perceptions of first class elementary school teachers on thematic learning are not appropriate to the requirements of Indonesian curriculum. In-depth training and socialization are needed to provide the teachers in implementing thematic learning in the classroom, so that learning objectives could be achieved. Teachers need to be introduced to various learning models with thematic approaches, so that teachers have proper understanding and perceptions that are related into the requirement of Indonesian curriculum. 


\section{ACKNOWLEDGEMENTS}

This research is a Higher Education Basic Research Grant (PDUPT) funded by DRPM Ristekdikti 2018. Therefore, thanks are addressed to: DRPM Ristekdikti, President of STKIP PGRI Sumatera Barat and UP3M STKIP PGRI Sumatera Barat, and LLDIKTI Region X.

\section{REFERENCES}

[1] P. Cave, Primary School in Japan. 2014.

[2] M. T. Wuryani and S. Yamtinah, "Textbooks Thematic Based Character Education on Thematic Learning Primary School: An Influence,” Int. J. Educ. Methodol., vol. 4, no. 2, pp. 75-81, 2018.

[3] A. Alex and T. K. Chen, "Bring Character Education into Classroom," Eur. J. Educ. Res., vol. 1, no. 2, pp. 163-170, 2012.

[4] S. Mardikarini and Suwarjo, "an Analysis of Character Values Content in the 2013 Curriculum,” Pendidik. Karakter, pp. 261-274, 2013.

[5] P. Anggraini and T. Kusniarti, "The Implementation of Character Education Model Based on Empowerment Theatre for Primary School Students," J. Educ. Pract., vol. 7 , no. 1, pp. 26-29, 2016.

[6] C. J. Huang, M. C. Liu, S. S. Chu, and C. L. Cheng, "An intelligent learning diagnosis system for Web-based thematic learning platform," Comput. Educ., vol. 48, no. 4, pp. 658-679, 2007.

[7] A. H. Hernawan and N. Resmini, "Konsep Dasar dan Model-model Pembelajaran Terpadu," pp. 1-35, 2010.

[8] E. W. Winarni, E. P. Purwandari, H. Lusa, and S. Dadi, "The Impact of Thematic Learning Integrated ICT in Tabot Bengkulu as Cultural Ceremony toward Social Interaction Knowledge in Elementary School," Asian J. Educ. Train., vol. 4, no. 2, pp. 70-74, 2018.

[9] C. S. Medellu, S. Lumingkewas, and J. F. Walangitan, "Democratization of learning through thematic assignment," Int. Educ. Stud., vol. 8, no. 4, pp. 111-121, 2015.

[10] Istiningsih, "Empowerment of Teachers in Implementing Thematic Learning Method," J. Educ. Pract., vol. 8, no. 3, pp. 64-70, 2017.

[11] M. Miles and M. Huberman, "Qualitative data analysis : an expanded sourcebook." Sage Publications, California, p. 338, 1994.

[12] U. Murfiah, "Model Pembelajaran Terpadu Di Sekolah Dasar," J. Pesona Dasar, vol. 1, no. 5, pp. 57-69, 2017.

[13] Y. D. Ariyani and M. N. Wangid, "The development of integrated-thematic teaching materials based on characters of environmental care and responsibility," J. Pendidik. Karakter, vol. VI, no. 1, pp. 116-129, 2016.

[14] N. A. Estuwardani and A. Mustadi, "Developing a Thematic-Integrative Learning Module to Promote," J. Pendidik. Karakter, vol. 5, no. 2, pp. 157-172, 2015.

[15] WWC, "Wwc Evidence Review Protocol for Character Education Interventions," Character Educ., pp. 1-11, 2014.

[16] F. Turan and I. Ulutas, "Using storybooks as a character education tools," J. Educ. Pract., vol. 7, no. 15, pp. 169-176, 2016.

[17] K. Saddhono and M. Rohmadi, "A Sociolinguistics Study on the Use of the Javanese Language in the Learning Process in Primary Schools in Surakarta, Central Java, Indonesia." Int. Edu. Stu., vol. 7 no.6 pp 25-30, 2014 
